\title{
Microbial contamination of groundwater in a swine fertigation area
}

\author{
Contaminação microbiológica da água subterrânea em área fertirrigada por dejeto suíno
}

\author{
Camila Bolognes Couto Pahl ${ }^{1}$, Giancarlo Lastoria ${ }^{1}$ and Sandra Garcia Gabas ${ }^{1}$ \\ ${ }^{1}$ Universidade Federal de Mato Grosso do Sul, Campo Grande, MS, Brasil \\ E-mails: camila.couto@ufms.br (CBCP), g.lastoria@ufms.br(GL), sandra.gabas@ufms.br (SGG)
}

Received: August 18, 2017 - Revised: December 18, 2017 - Accepted: February 05, 2018

\begin{abstract}
The use of swine effluents as a biofertilizer is an alternative to chemical fertilizers and to water demand in dry season. Nevertheless, fertigation studies usually focus on the plant demand and the soil nutrition parameters, mainly physic-chemical ones. This work aimed to evaluate the impacts of fertigation with swine effluents treated in the microbial quality of groundwater from the phreatic aquifer in two lots on Campanário settlement, on the city of São Gabriel do Oeste, MS, Brazil. Microbial analyses were carried out on groundwater samples from four piezometer and two supply wells using the Colilert system to quantify total coliform and Escherichia coli. Samples were collected during twelve months. The results indicate groundwater contamination by bacteria of the coliform group, according to the drinking water Brazilian standards and its spatial distribution from the point sources to a spreading area in accordance with groundwater flow. Therefore, water disinfection is strongly recommended for drinking purposes. Despite having a strong correlation with groundwater microbial contamination, especially in rainy season, fertigation with swine effluents seem not to be the only source of pathogens in the phreatic aquifer. However, high total coliform values in dry season samples could be assigned to the fertigation.
\end{abstract}

Keywords: Coliforms; Aquifer; Swine effluent.

\section{RESUMO}

O uso de efluente de suínos como biofertilizante é alternativa ao uso de fertilizantes químicos e principalmente à demanda de água em estação seca. Porém, os estudos de fertirrigação normalmente se concentram na demanda da planta e nos parâmetros de nutrição do solo, principalmente físico-químicos. O trabalho objetivou avaliar o impacto da fertirrigação com dejeto suíno tratado na qualidade da água subterrânea em aquífero livre em dois lotes no Assentamento Campanário, São Gabriel do Oeste, MS, Brasil. Foram realizadas análises microbiológicas em amostras de água subterrânea de quatro piezômetros e dois poços de abastecimento usando o método Colilert de quantificação de coliformes totais e Escherichia coli. As amostras foram coletadas durante doze meses. Os resultados indicam contaminação das águas subterrâneas por bactérias do grupo coliforme, de acordo com os padrões de potabilidade e a distribuição espacial de fontes pontuais a uma área de espalhamento devido ao gradiente do fluxo de águas subterrâneas. Portanto, a desinfecção da água é fortemente recomendada para fins de consumo humano. Apesar da forte correlação com a contaminação microbiológica da água subterrânea, a fertirrigação com efluente de suínos não deve ser a única fonte de patógenos no aquífero freático. No entanto, elevados valores de coliformes totais nas amostras da estação seca podem ser atribuídas a esta atividade.

Palavras-chave: Coliformes; Aquífero; Efluente suíno. 


\section{INTRODUCTION}

Population growth increases the demand for food and consequently the adoption of intensive production of animal protein, such as swine (SOBESTIANSKY; BARCELLOS, 2007). The swine business includes a world livestock of approximately 990 million heads and represents $40 \%$ of the total meat consumption in the world, making it the principal source of animal protein. China is the biggest producer of pork with $57 \%$ of the world production, followed by the European Union with 22\% and the Americas with 17\% (FAO, 2015).

There is strong expansion of swine in the Middle-West of Brazil, promoted by grain production, a case of integrated production between agriculture and animal feeding (BERGIER et al., 2012), causing reduction in production costs (MIELE; MIRANDA, 2013). In Mato Grosso do Sul State (MS), pig farms contribute to income and jobs, increasing the life quality of local population, as observed in São Gabriel do Oeste city, the MS main producer.

Disposing properly swine waste, also known as biofertilizer, as well the inclusion on the certification market of greenhouse gases emission reduction resulted in the installation of anaerobic biodigestor. The addition of biofertilizer to the soil, rich in ammoniacal nitrogen, is responsible for soil microorganisms stimulation, which is extremely beneficial for grain and forage production and, therefore, for liquid carbon emissions from fertirrigated soils in São Gabriel do Oeste (FERNANDES et al., 2011).

A growing concern of humanity is quantity and quality of public water supply, due to limit water resources availability and the deterioration of the quality of the water sources (BRASIL, 2006). Groundwater monitoring by enteric bacteria analyzes has the purpose of evaluating the sensitivity of the phreatic aquifer to the contamination, ensure the efficiency of the system and reduce the risk of diseases, which is seen by the population as a great purity water supply and that does not require treatment before its consumption.

Coliform group consists of bacilli bacteria, gram-negative, non-spore-forming, facultative, that ferment lactose with acid and gas production within 24 hours at $37^{\circ} \mathrm{C}$ temperature (APHA, 2012). Total coliforms includes bacteria originated from the gastrointestinal tract of humans and other warm-blooded animals, but also has several genera and species of non-enteric bacteria (SILVA et al., 2010). Thermotolerant coliforms are subgroup of total coliforms, with Escherichia coli being the main indicator of fecal contamination, since it is a common inhabitant of the intestinal tract of man and animals. Coliforms are not pathogenic under normal conditions, although some strains may cause diarrhea and opportunistic infections of the urinary tract (TORTORA, 2012; MURPHY et al., 2017).

The aim of the present study was to evaluate the groundwater quality of the phreatic aquifer in a fertirrigated area with treated swine effluent by microbial analyses. The presence of total coliforms in groundwater is understood as an evidence of contamination by surface water infiltration and the potential of fecal pathogens existence (PAYMENT; LOCAS, 2011). The higher levels of fecal bacteria in the environment the greater the likelihood of other pathogens also to be present (CARNEIRO et al., 2006). All the existing pig farms in São Gabriel do Oeste have waste treatment by biodigestor and the water supply systems in the urban and rural areas are exclusively from underground source.

\section{MATERIAL AND METHODS}

\section{Study area}

The study area is located in the Campanário rural settlement $\left(19^{\circ} 17^{\prime} 29.5\right.$ "S and $\left.54^{\circ} 36^{\prime} 16.3^{\prime \prime} \mathrm{W}\right)$, in the city of São Gabriel do Oeste (SGO), Mato Grosso do Sul, which comprises 132 lots, around 20 ha each one. This study was performed at 54 and 55 lots, both near the Coxim River spring, one of the principal tributary of the Taquari River. The settlement is located in the microregion of the Alto Rio Taquari Basin, Alto Paraguay watershed (Figure 1), one of the Guarani Aquifer recharge area in MS State.

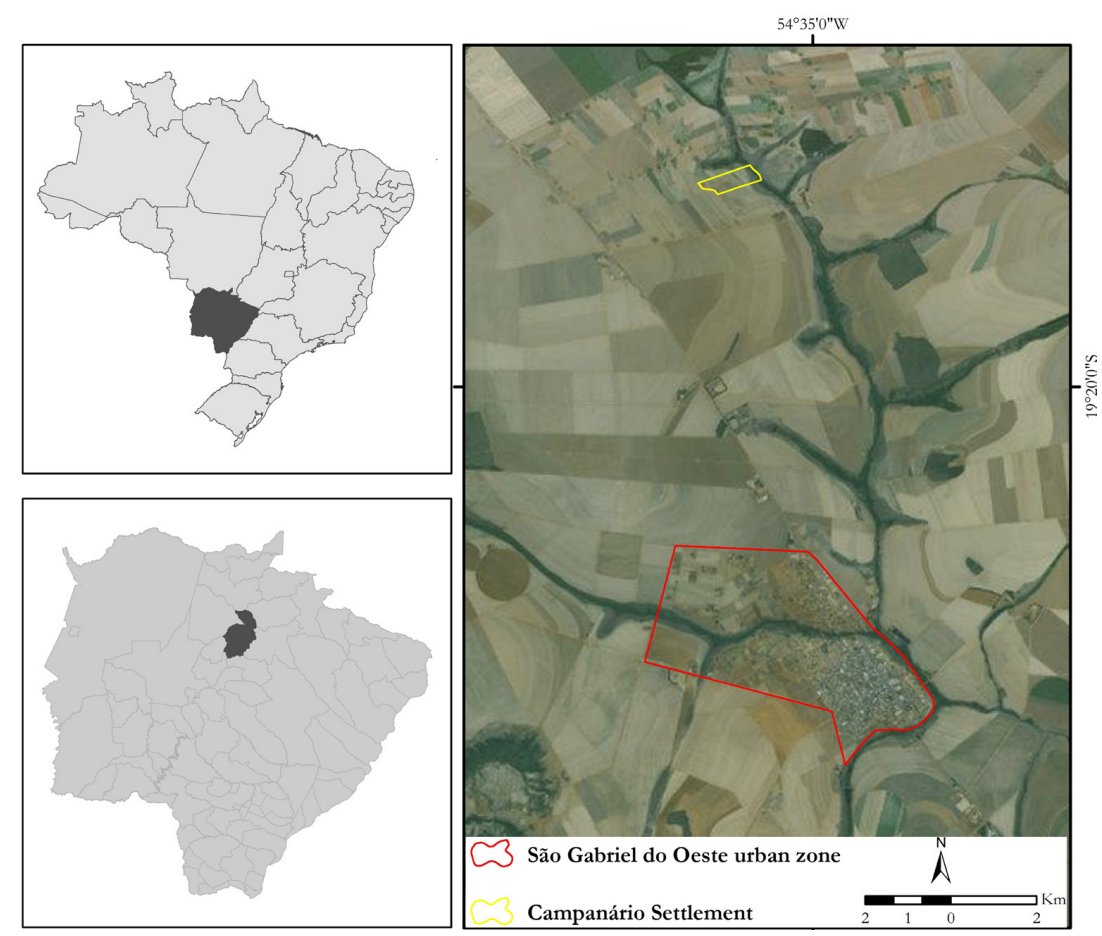

Figure 1. Location map of the study area. In red the urban area of São Gabriel do Oeste city and in yellow the Campanário settlement. 
The public water supply system of the city and the private ones, especially in farms, are exclusively from groundwater resources exploited from the Cenozoic and the Guarani Aquifers. In the urban area, six deep wells are exploited from Guarani Aquifer (120,000 $\mathrm{m}^{3}$ of water/month) (SAAE, 2013). The aquifer most exploited in the Campanário settlement is the Cenozoic Aquifer, which is derived from a Tertiary sedimentary deposit above the Guarani Aquifer (SOUZA et al., 2014).

In geological terms, all territory of the mentioned city is inserted in the Paraná Basin, a Paleozoic sequence of sedimentary and volcanic rocks. There are outcrops of rocks from the Tertiary Period (Detritus-lateritic coverage), Carboniferous Period, Itararé Group (Aquidauana Formation), Devonian Period, Paraná Group (Ponta Grossa Formation), Triassic Period, São Bento Group (Pirambóia, Serra Geral and Botucatu Formation), Jurassic Period, Upper Cretaceous (Bauru Group) and recent alluvium (MATO GROSSO DO SUL, 2011).

\section{Swine production}

Pig farming in São Gabriel do Oeste is noteworthy the largest pig producer in the state, with slaughter around 1,200 pigs per day in the Aurora slaughterhouse, according to Crispim et al. (2010). The lots produce biogas and biofertilizers (treated liquid effluent) coming from the anaerobic reactor of the pig farms (BULLER et al., 2015), which has capacity for manure treatment of two thousand animals, attending both lots in termination unit (BERGIER et al., 2012).

Continuous processing in the bioreactor has a hydraulic residence time of approximately 30 days with final effluent deposition in two maturation ponds (FERNANDES et al., 2011). Average water consumption per animal is around 10 liters per day and the annual biofertilizer production is $7,300 \mathrm{~m}^{3}$. The effluent from the second pond is periodically discharged on the area to be fertigated. The agricultural activities in the settlement were composed by two crop rotation system per year. In 2014 the intercropping system was corn and eucalyptus (crop-forestry system) and the discharges were done in January, March and August in the pasture located at point D. Study area has been fertigated for five years.

\section{Sampling}

Groundwater sampling from the phreatic aquifer in the study area was carried out monthly for microbial analyzes, from January to December of 2014, total of 12 field campaigns during the morning period. All the samples were in duplicates. We sampled at the 2 supply wells and 4 monitoring wells (piezometers) installed in the study area (Figure 2). In situ determinations, such as the static level (meter), $\mathrm{pH}$, air and water temperature (Celsius degree) and electrical conductivity $\left(\mu \mathrm{S} . \mathrm{cm}^{-1}\right)$, were performed in each sampling point with portable equipment: level meter, $\mathrm{pH}$ meter, analog thermometer and conductivity meter, respectively. All the samples were collected separately in $250 \mathrm{~mL}$ sterile adapted glass containers. After collection, water samples were identified, conditioned in refrigerated box and transported to the laboratory for analysis in accordance with the guidelines described by APHA (2012).

\section{Microbial analysis}

Quantification of Total Coliforms (TC) and Escherichia coli (EC) in each sample were carried out by using the Colilert system (Idexx Laboratories, Inc). The presence of total coliforms is indicated by a reaction that modifies the reagent coloration to yellow. In case of the presence of Escherichia coli, it is confirmed by exposing the

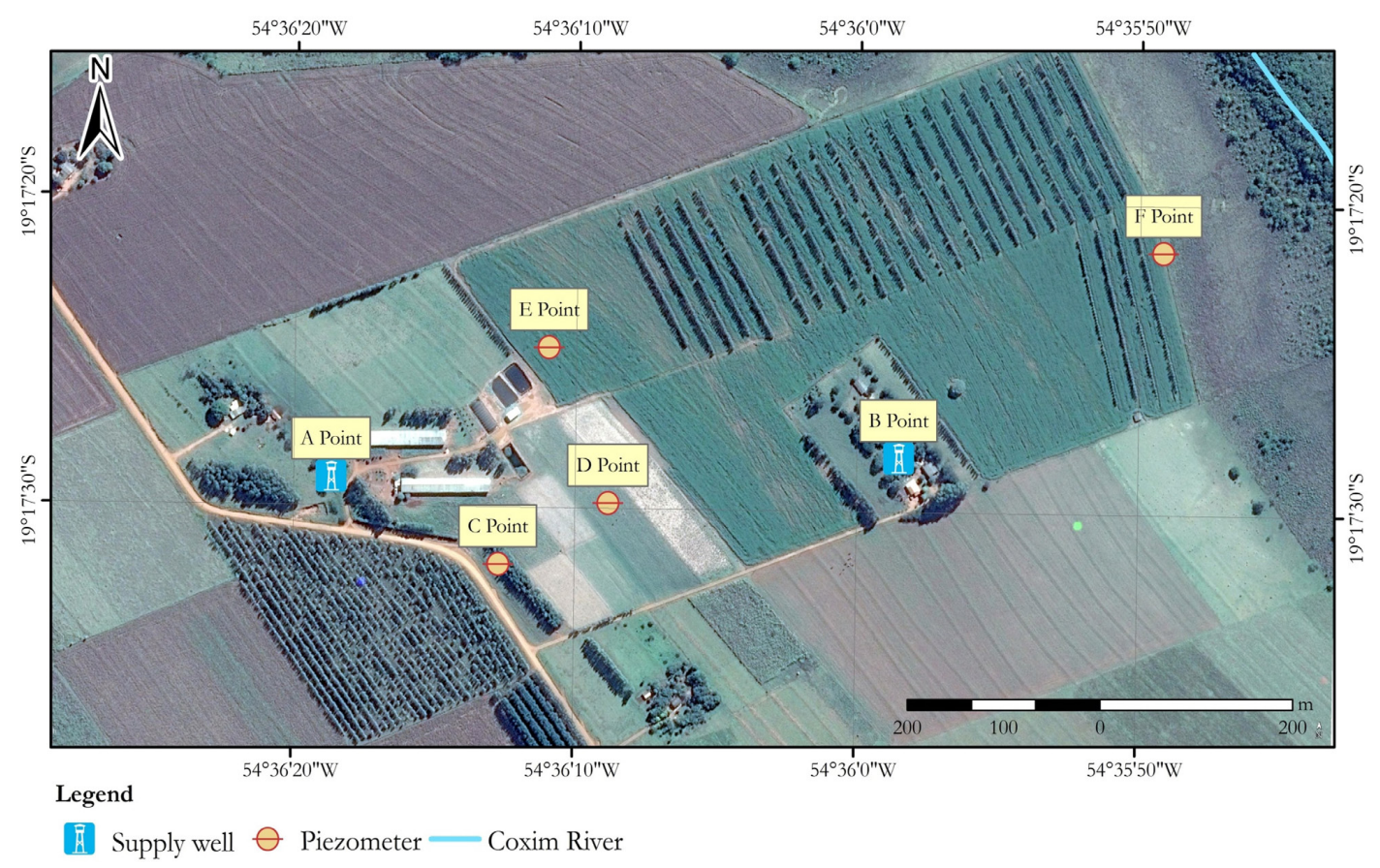

Figure 2. Supply and monitoring wells corresponding to groundwater collection. 
positive samples to total coliforms in ultraviolet light, showing blue fluorescence (SILVA et al., 2010).

From each water sample, $100 \mathrm{~mL}$ received the Colilert reagent, processed according to manufacturer's instructions, and incubated at $35{ }^{\circ} \mathrm{C} \pm 0.5$ for 24 hours providing the results by coloration and fluorescence. In some cases, it was necessary to dilute the sample for analysis. All enumerations were performed using the Most Probable Number (MPN) of total coliforms and E. coli, a quantification method range between $<1$ and 2,419 MPN per $100 \mathrm{~mL}$ of sample, using probability table with $95 \%$ confidence limit. The results are the average between duplicates of each sample.

After the microbial analysis, all samples were evaluated according to drinking water standards (BRASIL, 2011a,b) and groundwater framework (BRASIL, 2008).

The amount of infiltrated water in the soil directly affects the amount of surface runoff and groundwater recharge (LIU et al., 2011). This interferes in groundwater level, pathogen supply, $\mathrm{pH}$ and groundwater electrical conductivity. As there is not any hydrological study in the area, it is not possible to evaluate recharge in the studied aquifer. Therefore, the measured parameters were correlated with monthly accumulated precipitation, specifically in the rainiest month, February.

\section{RESULTS AND DISCUSSION}

\section{Microbial analysis}

Total coliforms results are presented in Figure 3. TC were present in all sample points during the monitoring period, including point $\mathrm{C}$, considered local background.

For some samples (point $F$ in February; points $C$ and $D$ in April; points D and E in May; point D in June, July, September, October and November; points $\mathrm{D}$ and $\mathrm{E}$ in December) quantitative results were above the maximum detectable limit of the method used for analysis of total coliforms (>2,419 MPN per $100 \mathrm{~mL}$ ), even though its previous dilution.

Escherichia coli was not detected in most of the analysis, but it was present in samples collected in the rainy season (Figure 4). Although the E. coli count had low values ( $<1$ to $27.5 \mathrm{MPN}$ ), the presence of these microorganisms is a concern and should be considered as an alert, indicating the possibility of other pathogens, such as Salmonella spp., Vibrio spp. and Giardia spp., as reported by Gonzalez, Paranhos and Lutterbach (2010).

Coliforms, TC and EC, increase after the months of soil effluent discharges (January, March and August), even in points that is not fertigated (Figure 5). Groundwater recharge results from effective rainfall (precipitation minus evapotranspiration

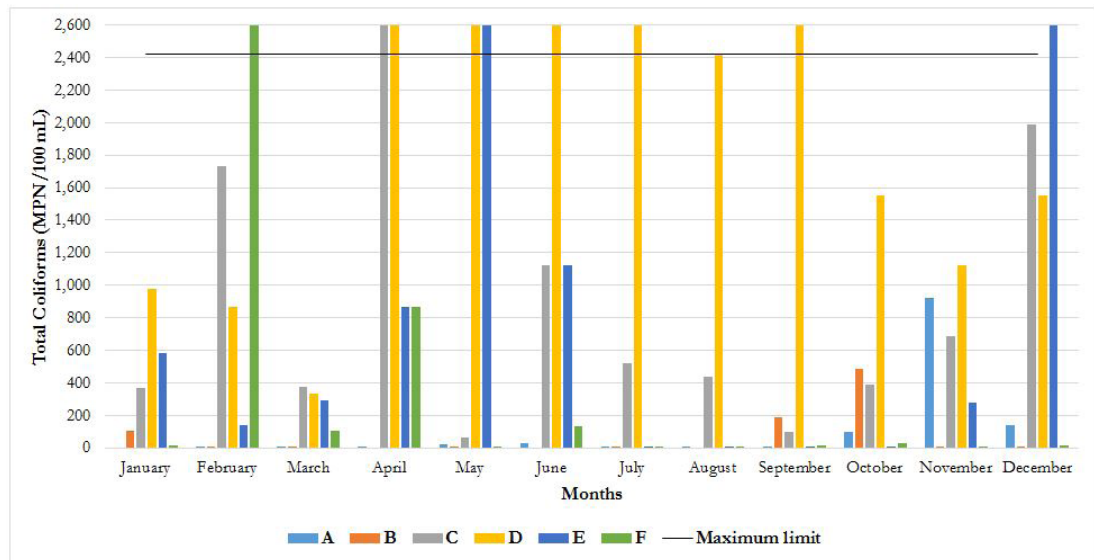

Figure 3. Quantitative results for total coliforms by sample of $100 \mathrm{~mL}$ of water, in six sampling sites during 2014. The continuous black line represents the detectable maximum limit of the Colilert system (2,419 MPN per $100 \mathrm{~mL})$. The samples of D point in October to December were diluted $10^{-1}$.

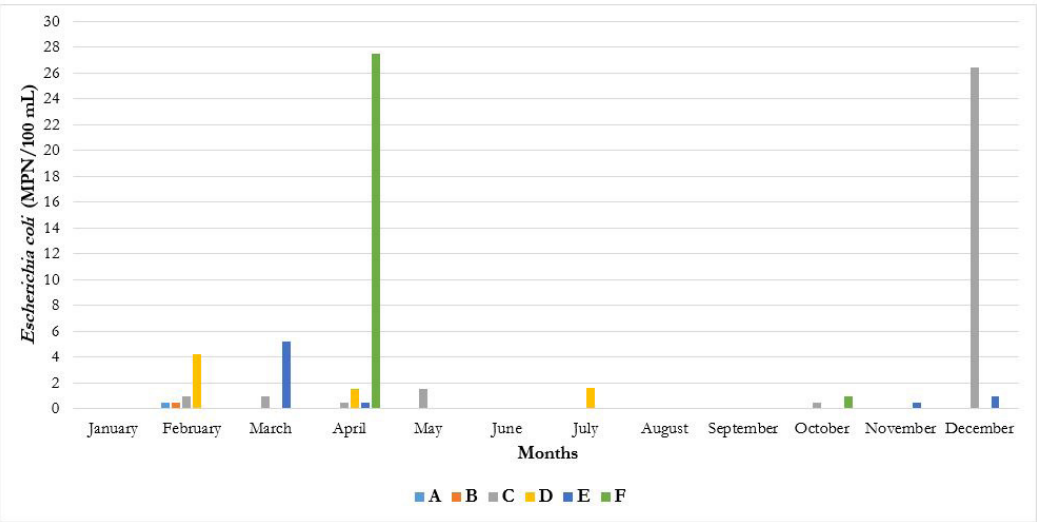

Figure 4. Quantitative results for Escherichia coli by sample of $100 \mathrm{~mL}$ of water, in six sampling sites during 2014. 


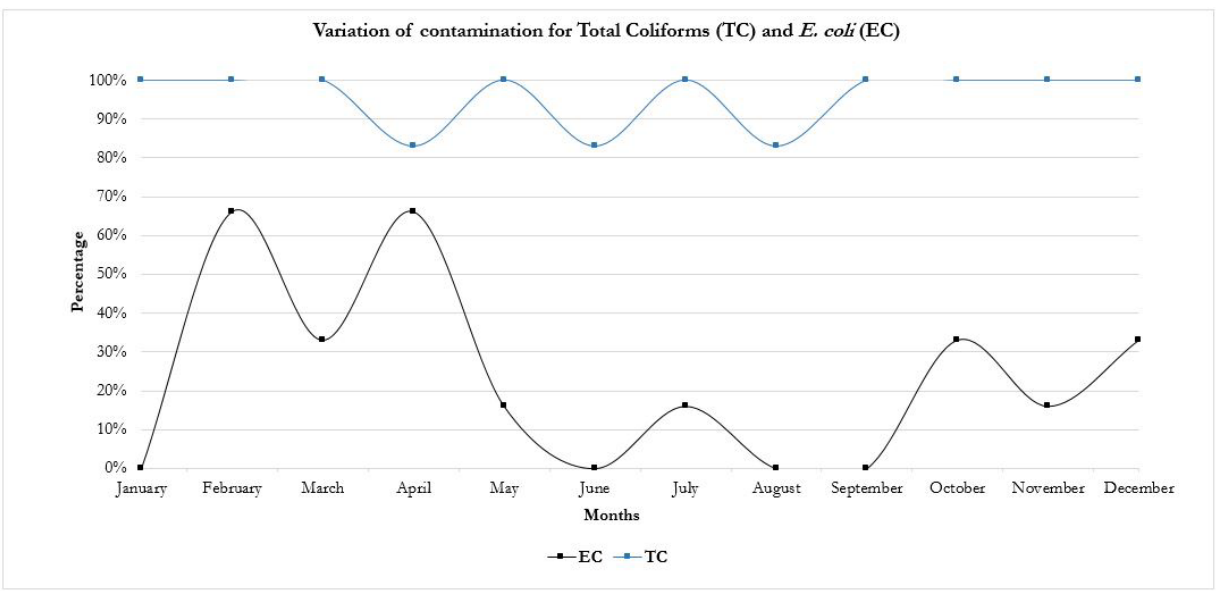

Figure 5. Percentage variation in contaminated wells by TCs and Escherichia coli monthly. Note that in rainy months (November to April) the percentage of coliforms, both total $(97.2 \%)$ as E. coli $(36 \%)$, increases.

and surface run-off) that infiltrates underground (TAYLOR et al., 2013). Rainy season months were from November to April and the dry season from May to October. February was the wettest month $(420 \mathrm{~mm})$ and the driest one was August $(0 \mathrm{~mm})$, summed up to 2,102 $\mathrm{mm}$ of accumulated precipitation in 2014 (Figure 6).

Rainy season matches to the greatest relative frequency of pathogens, TC and E. coli. As previously mentioned, although the frequency of E. coli is lower than total coliforms there is a potential risk of the occurrence of other pathogenic organisms in the water. High TC values in dry season samples (May to October) could be partially assigned to fertigation with swine effluent.

The presence of microorganisms in soil is well recorded, mainly by agricultural studies (GILLER et al., 1997; HERMANS et al., 2017). There are some concern in groundwater studies (CHAPELLE, 2000; HUMPHREYS, 2009; MURPHY et al., 2017; KLOVE et al., 2017), but their behavior in vadose zone as well as in saturated zone is still poorly understood (MCKAY, 2011; HUNT; JOHNSON, 2017). Nevertheless, there are some evidence that sandy soil is not capable to retain microorganisms such as E. coli (WANG et al., 2011).

This problem is crucial in delimiting protecting areas of wells for human supply near of these discharges (MANOEL FILHO, 2008; KLOVE et al., 2017). Regarded to the study area, there is a sandy soil and a shallow aquifer, some characteristics that contribute to the movement of groundwater, increasing the risk of contamination mainly in rainy periods.

Groundwater flow in the study area moves, generally, from point $\mathrm{A}$ to point $\mathrm{F}$ (Figure 7) towards a discharge zone, the Coxim River. This flow pattern is also present in the dry season. Regarding the flow direction, the fertigated area (D) could interfere in the downstream areas, explaining the presence of pathogens in points $\mathrm{B}$ and $\mathrm{E}$. It is important to note that point $\mathrm{E}$ is not fertigated. Nevertheless, it is situated downstream the effluent pond.

According to Ferraro, Gabas and Lastoria (2015), samples of the swine effluent treated by bioreactor in the same area of study presented concentrations of total coliforms in 129,970 MNP per $100 \mathrm{~mL}$ and 77,010 MNP per $100 \mathrm{~mL}$ for Escherichia coli. There is no regulation in Brazil concerned to physical-chemical

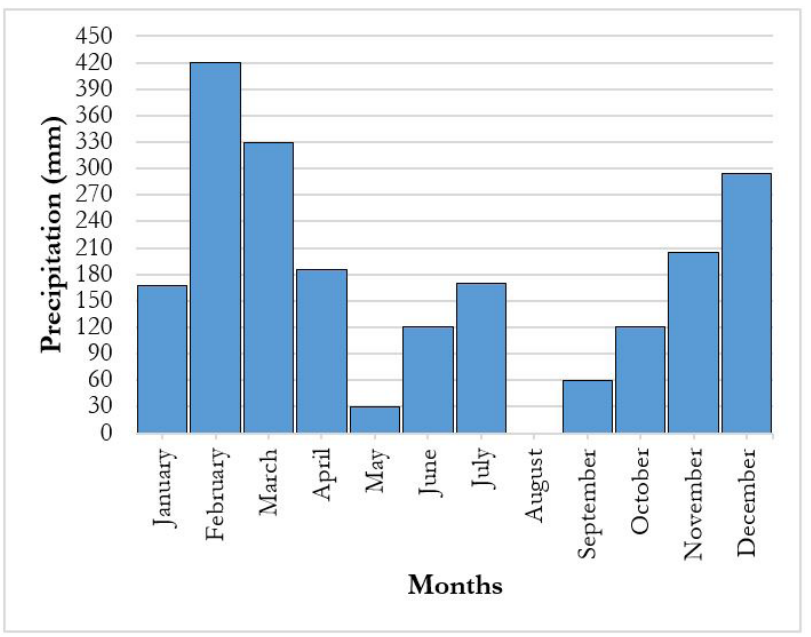

Figure 6. Accumulated precipitation monthly in 2014.

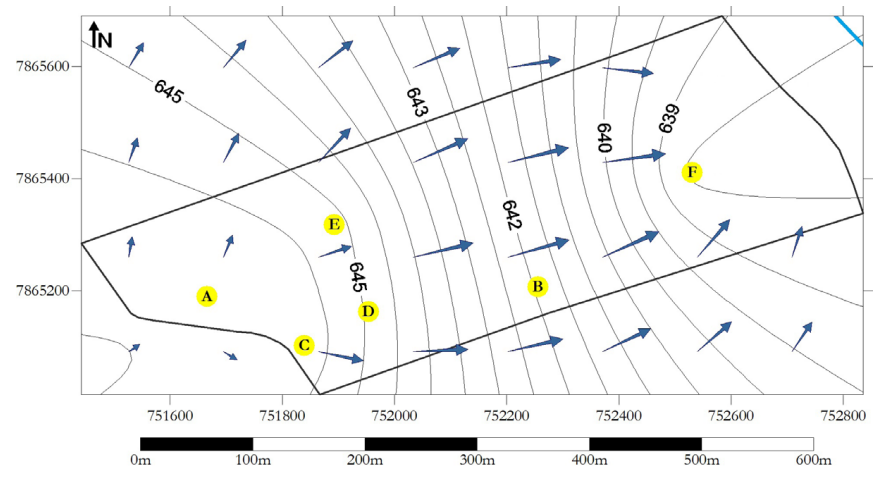

Figure 7. Groundwater flow of the study area. The blue line in northeast is located the Coxim River.

and microbiological safety parameters for animal effluents disposal in soil.

In the most rainy month (February), TC were detected in all sampled points (Figure 8), showing a positive correlation between precipitation and microorganisms infiltration towards the water 
table. This pattern was observed during the total rainy season. Reaching the phreatic aquifer, pathogens were diluted and carried downgradient by the groundwater flow to the entire area. On the other hand, TC and E. coli were concentrated at the point that received the effluent fertigation, point D (Figure 9) in the driest month (August). According to Trabulsi and Alterthum (2015), the increase of precipitation brings high and rapid establishment of new communities of these microorganisms.

Points $\mathrm{A}$ and $\mathrm{B}$ have lower TC values than points $\mathrm{C}, \mathrm{D}, \mathrm{E}$ and $\mathrm{F}$. This is could be explained by the depths of A and B wells ( 60 and $30 \mathrm{~m}$, respectively) and the presence of $2 \mathrm{~m}$ thick clay layer at depths below $10 \mathrm{~m}$. Point $\mathrm{D}$ showed higher TC values during all the year. Higher microbial concentration in point $\mathrm{D}$ is possibly due to the location of this piezometer in the most fertigated area. Nonetheless, point $\mathrm{C}$, which is located upstream from the fertigation area, had pathogens in every month. Microbial presence upstream the fertigated area could be attributed to natural presence of this in the area as observed by Hong et al. (2013) and Fridrich et al. (2014).

Microbial distribution pattern observed in the studied area is similar to that described by Brouyère, Dassargues and Hallet (2004), where variations in groundwater level affect the progress of the contamination. In periods of groundwater level rising, contaminants infiltrate into the soil profile and the unsaturated zone is lixiviated, inducing an increase of pollutants in the aquifer. When the groundwater level falls, the contamination front is disconnected from the saturated zone and the pollutants concentrations decrease.
Bacterial population composed of a small number of adhered bacteria can become to suspended bacteria with a large numbers of cells that can be transported by the groundwater flow and therefore contaminate water sources in downstream areas of the aquifer. Due to higher precipitation in summer and the aquifer recharge, the suspended cells can be transport faster towards water resources (KIM; KIM, 2012). On the other hand, comparing the amount of microbial organisms in the effluent from the pond (FERRARO; GABAS; LASTORIA, 2015) and in the groundwater results, it is evident that soil retains most of the microorganisms.

The relationship between accumulated precipitation with the TC values of the six monitoring points could be seen in Figure 10 to 15 . They indicate the rain interference in the amount of pathogens in groundwater.

Survival of coliforms in subsoil is usually limited. Therefore, their detection in groundwater is an evidence of a connection between pathogens source and groundwater. According to drinking water Brazilian legislation (BRASIL, 2011a,b) and to groundwater Brazilian standards (BRASIL, 2008), TC and E. coli in water samples analyzed were above the established limits, the total coliforms and Escherichia coli count should be absent in $100 \mathrm{~mL}$ of water sample.

Untreated water from phreatic aquifer is used for drinking purposes, exploited from supply wells A and B. The Campanário settlement does not have a public water supply system (except at the Community Center that have monitoring well by SAAE); therefore, most of the properties have private shallow wells for

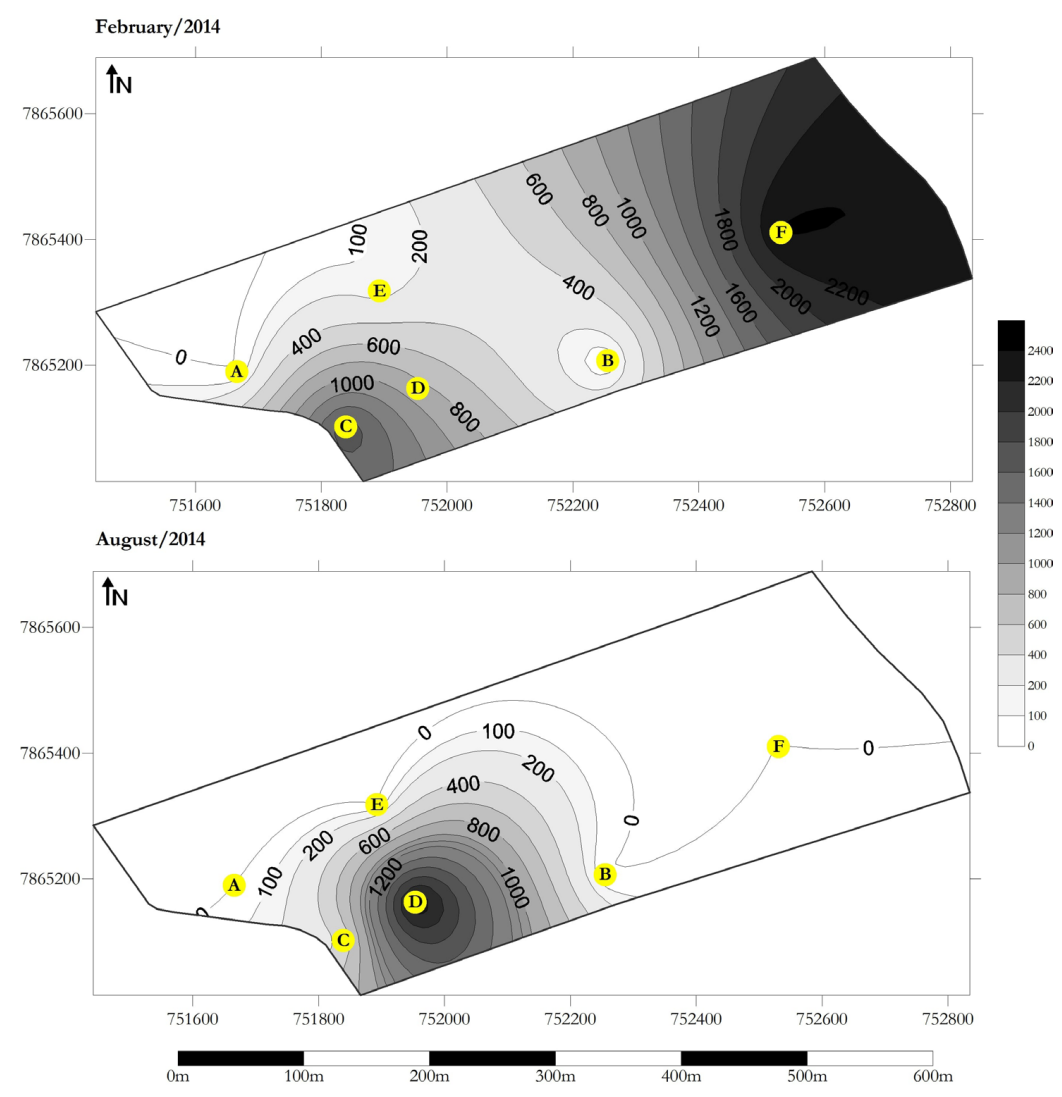

Figure 8. Most probable number of total coliforms in rainy season (February) and dry season (August), respectively. 


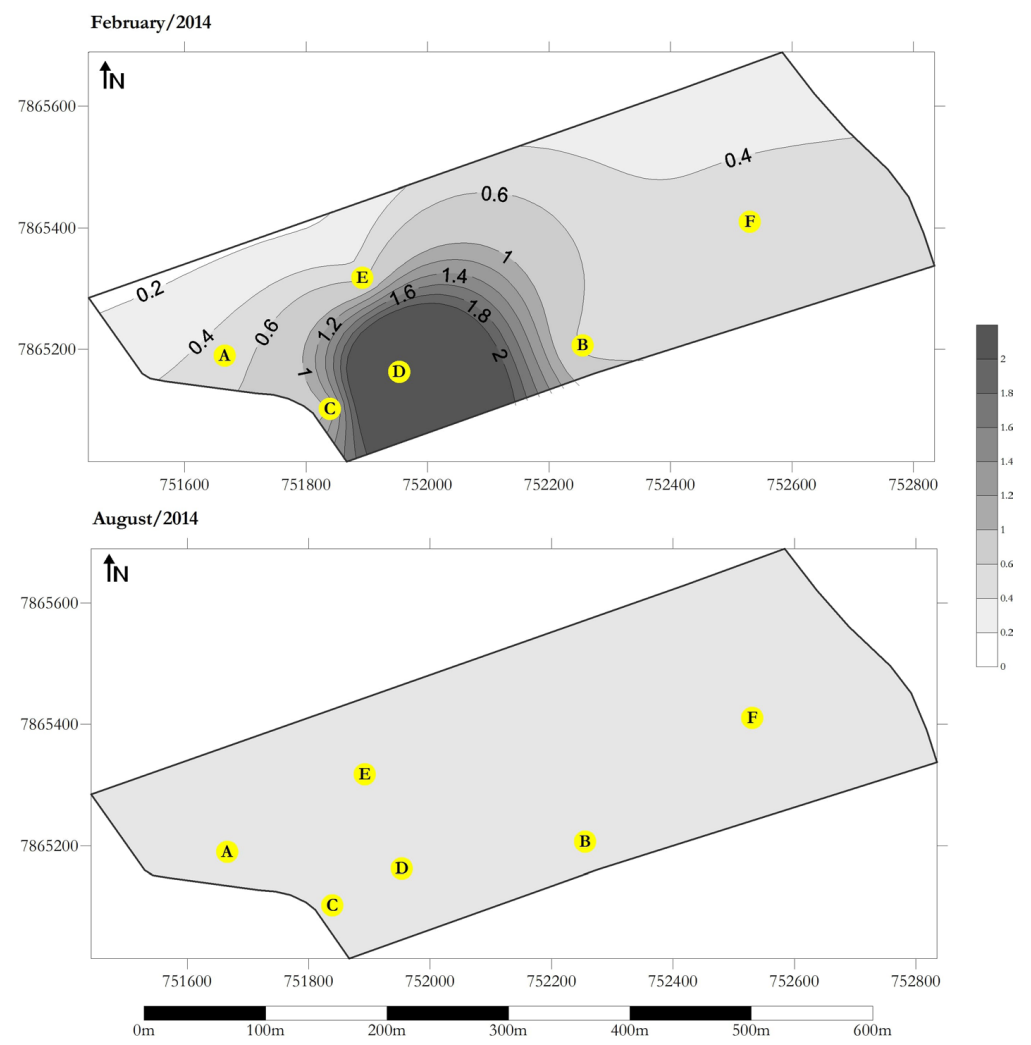

Figure 9. Most probable number of Escherichia coli in rainy season (February) and dry season (August), respectively.

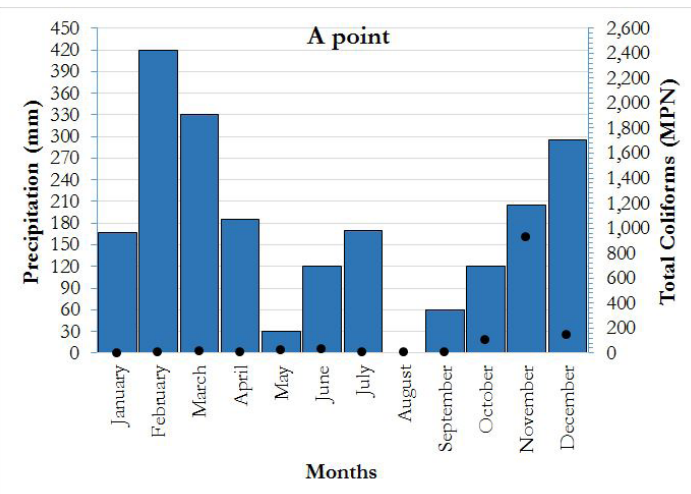

Figure 10. Annual precipitation ( $\mathrm{mm}) \mathrm{X}$ Total coliforms (MPN) in Point A.

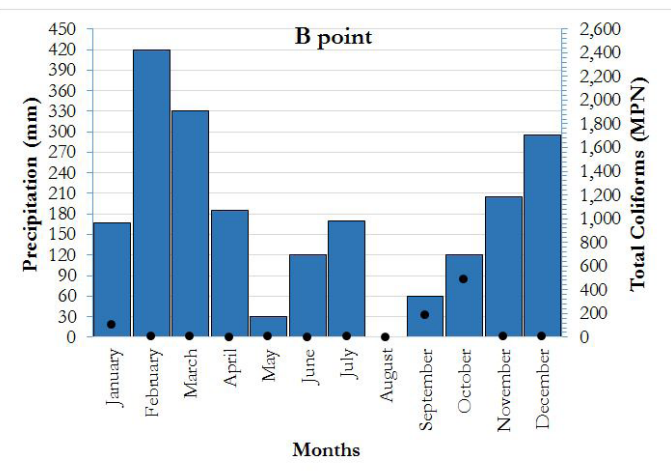

Figure 11. Annual precipitation (mm) X Total coliforms (MPN) in Point B.

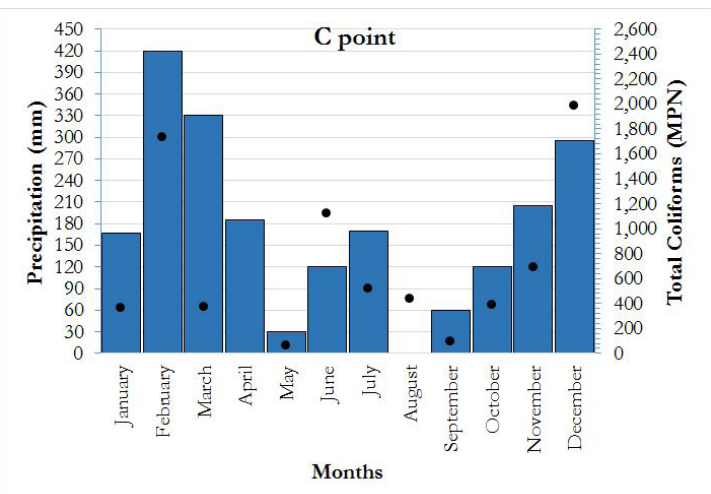

Figure 12. Annual precipitation (mm) X Total coliforms (MPN) in Point C.

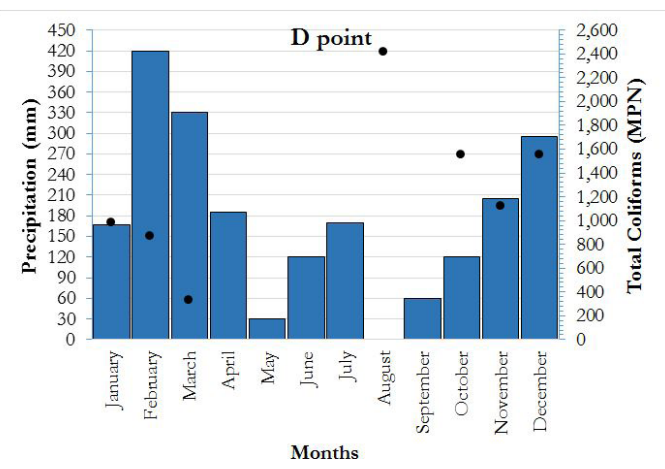

Figure 13. Annual precipitation ( $\mathrm{mm}$ ) X Total coliforms (MPN) in Point D. The samples were diluted $10^{-1}$ from October to December. 
consumption. There is a risk of human infection, as the people consume the water since the beginning of the agrarian reform project in November of 1997 (GUEDES; SALLES, 2006).

\section{Physical chemical analysis}

The parameters, water table/piezometric level (meters), $\mathrm{pH}$, air temperature (Celsius degree), water temperature (Celsius degree) and electrical conductivity $(\mu$ S.cm-1) are presented in Table 1.
For drinking water pH should be between 6.0 to 9.5 (BRASIL, 2011a). These values are compatible with those obtained from the water analyzes in all the points sampled. The average $\mathrm{pH}$ for points A, B, C, D, E and F were 7.1; 6.3; 6.7; 6.9; 6.7 and 7.4, respectively. In contrast, the $\mathrm{pH}$ observed in groundwater is great for bacterial growth.

Electrical conductivity values for each point sampled presented higher in the winter than in the summer, as expected. This seasonal difference occurs to the dilution effect of rainy

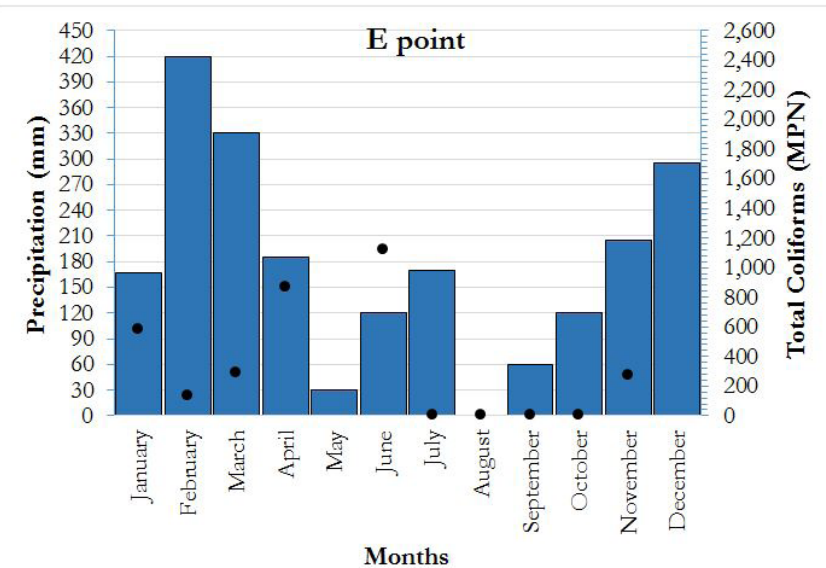

Figure 14. Annual precipitation (mm) X Total coliforms (MPN) in Point E.

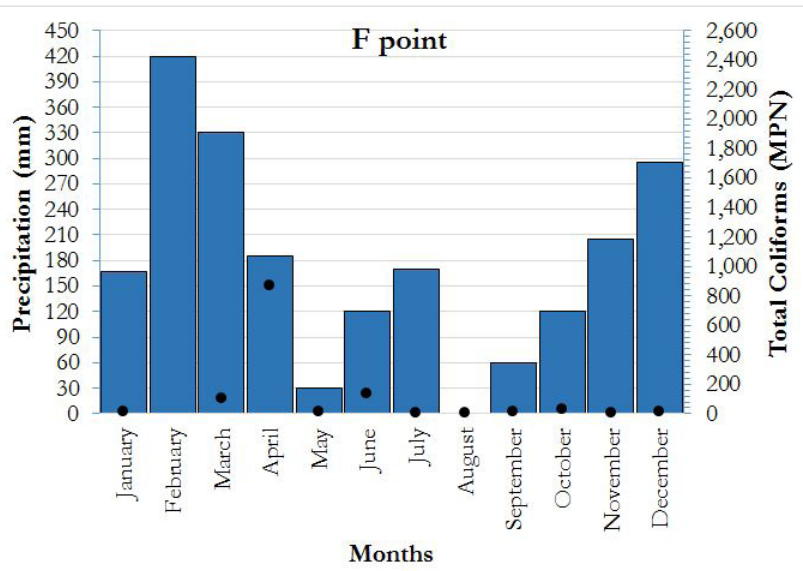

Figure 15. Annual precipitation (mm) X Total coliforms (MPN) in Point $F$.

Table 1. Results of physical chemical parameters in groundwater samples from field campaigns during 2014.

\begin{tabular}{|c|c|c|c|c|c|c|c|c|c|c|c|c|c|}
\hline Sites & Par. & Jan. & Feb. & Mar. & Apr. & May & Jun. & Jul. & Aug. & Sep. & Oct. & Nov. & Dec. \\
\hline \multirow[t]{4}{*}{$\mathbf{A}$} & $\mathrm{pH}$ & NM & 6.1 & 5.8 & 6.5 & 7.4 & 6.8 & 5.9 & 7.5 & 5.3 & 8.6 & 8.5 & 9.8 \\
\hline & $\mathrm{T}^{\circ} \mathrm{a}$ & NM & 24.4 & 30.0 & 25.0 & 24.0 & 29.0 & 29.5 & 26.0 & 35.0 & 29.0 & 34.0 & 27.0 \\
\hline & $\mathrm{T}^{\circ} \mathbf{w}$ & NM & 24.0 & 25.5 & 24.8 & 25.0 & 25.0 & 25.1 & 25.1 & 25.5 & 25.3 & 25.2 & 25.0 \\
\hline & EC & NM & 3.3 & 6.1 & 4.7 & 5.7 & 5.6 & 6.6 & 6.2 & 6.9 & 6.8 & 5.9 & 6.2 \\
\hline \multirow[t]{4}{*}{ B } & $\mathrm{pH}$ & 5.3 & 5.0 & 5.6 & 6.2 & 7.4 & 5.6 & 6.1 & 6.5 & 5.1 & 7.8 & 8.3 & 7.1 \\
\hline & $\mathrm{T}^{\circ} \mathrm{a}$ & NM & 24.0 & 32.0 & 27.0 & 29.0 & 31.0 & 29.0 & 35.0 & 36.0 & 30.0 & 30.0 & 32.0 \\
\hline & $\mathbf{T}^{\circ} \mathbf{w}$ & 25.8 & 24.5 & 25.4 & 24.8 & 25.0 & 25.0 & 24.5 & 25.0 & 25.1 & 25.1 & 25.0 & 26.1 \\
\hline & EC & 6.8 & 15.4 & 6.4 & 6.4 & 6.1 & 6.6 & 6.8 & 6.6 & 6.5 & 5.3 & 7.5 & 5.5 \\
\hline \multirow[t]{5}{*}{ C } & WT & NM & 9.2 & 8.8 & 8.6 & 8.7 & 8.9 & 9.1 & 9.2 & 9.3 & 9.6 & 9.3 & 9.1 \\
\hline & $\mathrm{pH}$ & 5.7 & 5.7 & 5.8 & 6.4 & 7.4 & 5.6 & 6.1 & 7.4 & 6.0 & 9.3 & 8.3 & 6.4 \\
\hline & $\mathrm{T}^{\circ} \mathrm{a}$ & NM & 26.0 & 30.0 & 24.0 & 24.0 & 27.5 & 29.0 & 31.0 & 34.0 & 29.0 & 28.0 & 30.0 \\
\hline & $\mathbf{T}^{\circ} \mathbf{w}$ & 25.5 & 24.1 & 25.0 & 23.8 & 24.0 & 25.0 & 24.5 & 25.0 & 25.4 & 24.8 & 25.9 & 24.7 \\
\hline & EC & 9.4 & 9.3 & 7.8 & 8.6 & 8.7 & 8.0 & 6.8 & 8.8 & 8.2 & 8.2 & 8.1 & 7.6 \\
\hline \multirow[t]{5}{*}{ D } & WT & NM & 8.1 & 7.3 & 7.2 & 7.5 & 7.7 & 8.0 & 8.0 & 8.2 & 8.3 & 8.2 & 7.9 \\
\hline & $\mathrm{pH}$ & 5.8 & 5.6 & 7.3 & 6.7 & 7.8 & 6.7 & 6.8 & 7.1 & 5.5 & 8.9 & 8.3 & 6.4 \\
\hline & $\mathrm{T}^{\circ} \mathrm{a}$ & NM & 28.9 & 32.0 & 27.0 & 31.0 & 30.0 & 29.5 & 37.0 & 34.0 & 30.0 & 30.0 & 34.0 \\
\hline & $\mathbf{T}^{\circ} \mathbf{w}$ & 24.2 & 24.6 & 25.3 & 24.1 & 25.0 & 25.5 & 24.3 & 25.0 & 25.4 & 25.3 & 24.3 & 24.8 \\
\hline & EC & 5.8 & 6.2 & 5.6 & 5.3 & 12.3 & 5.0 & 6.0 & 7.2 & 6.4 & 5.7 & 5.4 & 9.3 \\
\hline \multirow[t]{5}{*}{ E } & WT & NM & 6.8 & 5.7 & 6.1 & 6.3 & 6.5 & 6.8 & 6.8 & 7.1 & 7.9 & 6.7 & 6.3 \\
\hline & $\mathrm{pH}$ & 5.4 & 5.7 & 7.0 & 7.5 & 7.6 & 6.9 & 6.4 & 7.2 & 5.4 & 8.1 & 7.0 & 6.1 \\
\hline & $\mathrm{T}^{\circ} \mathrm{a}$ & NM & 30.3 & 31.0 & 26.0 & 32.0 & 30.0 & 30.0 & 38.0 & 34.0 & 27.0 & 30.0 & 31.0 \\
\hline & $\mathbf{T}^{\circ} \mathbf{w}$ & 25.4 & 24.1 & 26.2 & 23.9 & 25.0 & 25.0 & 27.5 & 26.4 & 26.2 & 25.0 & 24.3 & 24.6 \\
\hline & EC & 10.3 & 13.2 & 17.8 & 19.7 & 24.2 & 21.8 & 22.4 & 22.5 & 19.2 & 15.3 & 14.6 & 13.6 \\
\hline \multirow[t]{5}{*}{ F } & WT & NM & 0.6 & 1.1 & 0.8 & 1.1 & 1.1 & 1.0 & 1.3 & 1.5 & 1.0 & 1.0 & 0.9 \\
\hline & $\mathrm{pH}$ & 5.6 & 7.4 & 7.9 & 7.6 & 7.7 & 5.3 & 7.3 & 6.5 & 7.1 & 10.0 & 8.7 & 7.6 \\
\hline & $\mathrm{T}^{\circ} \mathrm{a}$ & NM & 30.7 & 31.5 & 26.0 & 30.0 & 28.0 & 28.5 & 38.5 & 33.0 & 28.0 & 29.0 & 30.0 \\
\hline & $\mathbf{T}^{\circ} \mathbf{w}$ & 26.0 & 25.0 & 28.4 & 25.3 & 25.0 & 25.0 & 23.2 & 26.2 & 26.1 & 26.6 & 26.5 & 24.2 \\
\hline & EC & 5.9 & 8.2 & 7.8 & 7.6 & 9.6 & 11.6 & 7.1 & 5.8 & 7.2 & 6.3 & 6.7 & 6.6 \\
\hline
\end{tabular}

Subtitles: Par.: Parameters; NM: Item not measured in the field; WT: Water Table; $\mathrm{pH}$ : $\mathrm{pH}$; $\mathrm{T}^{\mathrm{o}}$ a: Air temperature; T${ }^{\mathrm{o}}$ w: Water temperature; EC: Electrical Conductivity. 
season causes ionic concentration in the groundwater in the dry season, allowing higher values of electrical conductivity in the winter (PENG et al., 2014). The average electrical conductivity for points A, B, C, D, E and F were 5.8; 7.2; 8.3; 6.7; 17.9 and 7.5, respectively.

Figure 16 shows the increase of the electrical conductivity value at point $\mathrm{E}$, in August, the driest month. This can characterize the contamination of the aquifer with effluent coming from the maturation pond, since this point is located downstream of the pond in the direction of the groundwater flow.
Water temperature is a limiting factor in bacterial growth, influencing their survival in water. For human consumption, high temperatures increase the rejection of water use (BRASIL, 2006). The average water temperature for points A, B, C, D, E and F were 25.0; 25.1;24.8; 24.8; 25.3 and 25.6, respectively.

Besides investigating the presence of microorganisms, it is important to evaluate their permanence and distribution in saturated zone, since it seems to be conceptual and practical differences between pathogens transport and traditional chemical contaminant transport (HUNT; JOHNSON, 2017).

\section{February/2014}

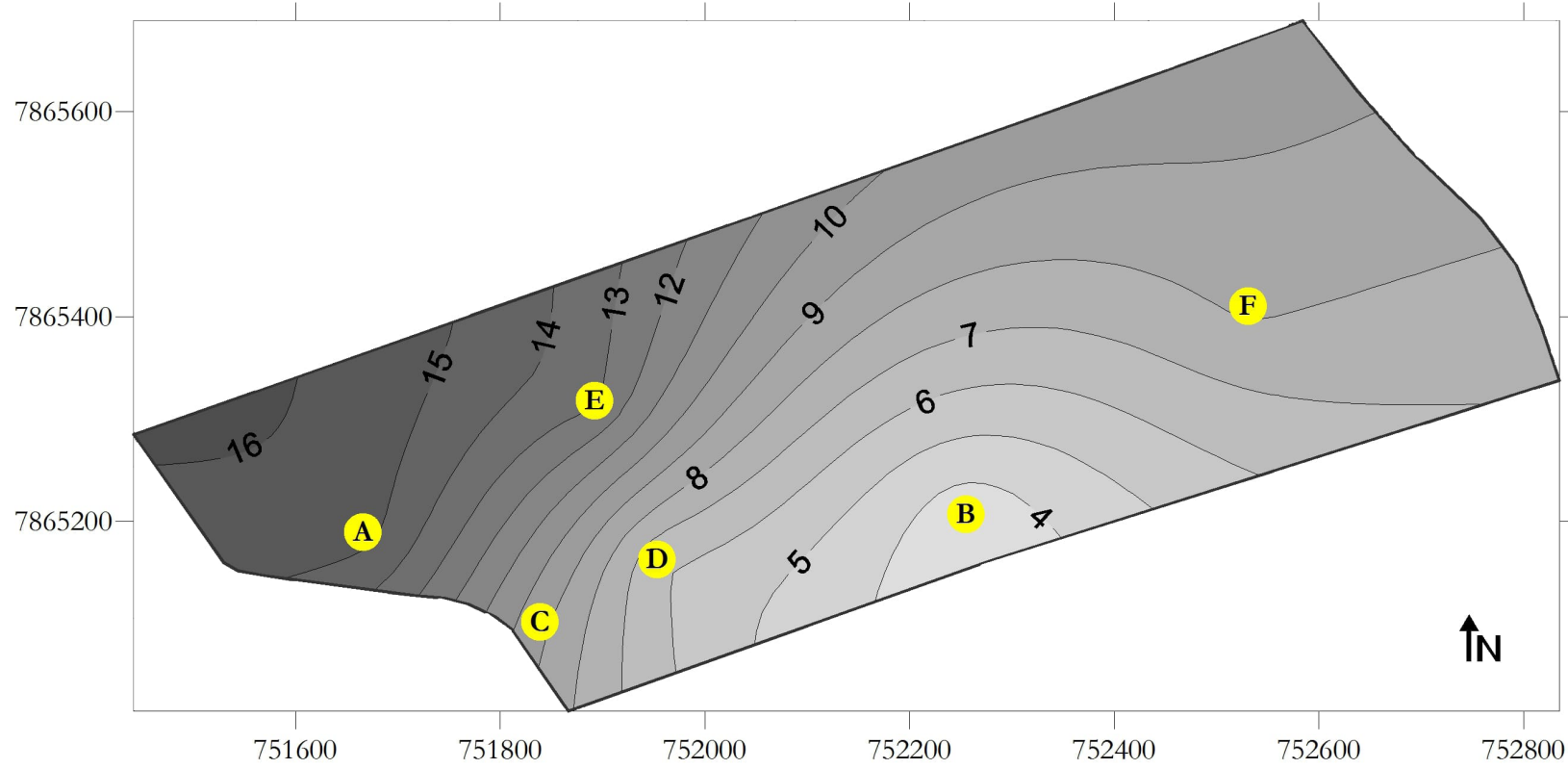

August/2014

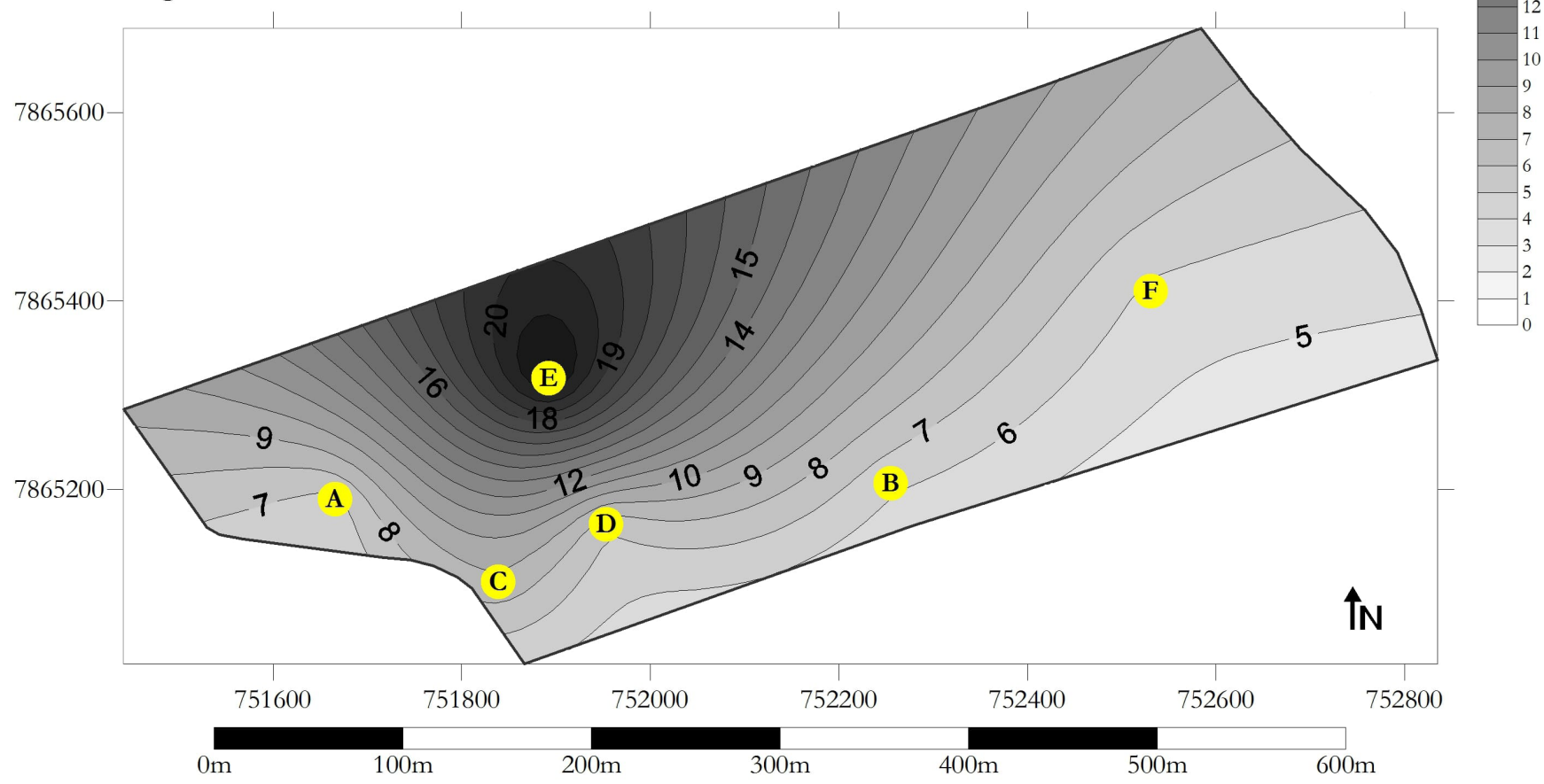

Figure 16. Electrical conductivity in the months of February and August in 2014. 


\section{CONCLUSIONS}

Groundwater samples were collected in a fertigation area during one hydrological year. Microbial and physical chemical analyses were carried out for quality purposes.

Although the application of organic effluents to crops is an alternative to the use of chemical fertilizers and mainly to water demand in dry season, it should be carefully analyzed in places where shallow groundwater resources are exploited to human supply. Groundwater from the Cenozoic Aquifer wells at the study area are inappropriate for human consumption from a bacteriological point of view, according to Brazilian legislation. The presence of E. coli indicates the possibility of the existence of other pathogenic bacteria, as well as viruses, protozoa and fungi from contact with fecal material. Therefore, a disinfection process is strongly recommended for drinking usage.

In addition, seasonal distribution of total coliforms and Escherichia coli indicated a relationship between the contamination rate and periods of higher rainfall, usually in summer. Spatial distribution of microbial results confirm the point sources of effluent discharge and its dispersion according to groundwater flow direction. Results suggest that fertigation is a source of pathogens in phreatic aquifers but it could not be attributed as the unique source. Therefore, additional studies should be carried out in order to investigate microbial as environmental impact indicators.

Nevertheless, some physical chemical parameters such as $\mathrm{pH}$, temperature and electrical conductivity are all according the drinking purpose legislation.

Groundwater quality in phreatic aquifers depends directly to human activity and only becomes a safety source of water supply if adopted according to the development and land use plan. Surface water and groundwater monitoring is recommended in order to enable effective water management in the area.

\section{ACKNOWLEDGEMENTS}

The authors would like thank to the Federal University of Mato Grosso do Sul (UFMS), the Agriculture Cooperative of São Gabriel do Oeste (COOASGO), the Brazilian Agricultural Research Corporation (EMBRAPA Pantanal) and the Campanário Settlement landlords, Antenor Barbosa de Oliveira and Roque Busanello, for allowing studies in their lots.

\section{REFERENCES}

APHA - AMERICAN PUBLIC HEALTH ASSOCIATION. Standard methods for the examination of water and wastewater. 22. ed. Washington: APHA, 2012.

BERGIER, I.; GOULART, T.; FRANCO, E.; RECH, R.; SILVA, D. S.; OLIVEIRA, G. S.; ALVES, L.F.; MORAES, A.; KOSOSKI, A. R.; SANTOS, K.; BULLER, L. S.; ORTEGA, E.; FERNANDES, C.; SILVA, R.; SILVA, P.; GABAS, S. G.; LASTORIA, G.; MORAES, O.; RAMOS, F. M.; RIBEIRO, T. T. Fertirrigação e agricultura de baixa emissão de carbono: resultados do projeto CNPq/REPENSA em São Gabriel do Oeste. Corumbá: Embrapa Pantanal, 2012.
BRASIL. Ministério da Saúde. Secretaria de Vigilância em Saúde. Vigilância e controle da qualidade da água para consumo humano. Brasília: Ministério da Saúde, 2006.

BRASIL. Conselho Nacional de Meio Ambiente. Resolução CONAMA n 396, de 3 de abril de 2008. Dispõe sobre a classificação e diretrizes ambientais para o enquadramento das águas subterrâneas e dá outras providências. Diário Oficial [da] República Federativa do Brasil, Brasília, DF, 7 mar. 2008, Sec. 1.

BRASIL. Conselho Nacional de Meio Ambiente. Resolução $\mathrm{n}^{\circ} 430$, de 13 de maio de 2011. Dispõe sobre as condições de lançamento de efluentes, complementa e altera a Resolução $\mathrm{n}^{\circ}$ 357, de 17 de março de 2005, do Conselho Nacional do Meio Ambiente - CONAMA. Diário Oficial [da] República Federativa do Brasil, Brasília, DF, 16 maio 2011a.

BRASIL. Ministério da Saúde. Portaria no 2914, de 12 de dezembro de 2011. Dispõe sobre os procedimentos de controle e de vigilância da qualidade da água para consumo humano e seu padrão de potabilidade. Diário Oficial [da] República Federativa do Brasil, Brasília, DF, 12 dez. 2011b.

BROUYÈRE, S.; DASSARGUES, A.; HALLET, V. Migration of contaminants through the unsaturated zone overlying the Hesbaye chalky aquifer in Belgium: a field investigation. Journal of Contaminant Hydrology, v. 72, n. 1-4, p. 135-164, 2004. http:/ / dx.doi.org/10.1016/j.jconhyd.2003.10.009. PMid:15240170.

BULLER, L. S.; BERGIER, I.; ORTEGA, E.; MORAES, A.; BAYMA-SILVA, G.; ZANETTI, M. R. Soil improvement and mitigation of greenhouse gas emissions for integrated croplivestock systems: Case study assessment in the Pantanal savanna highland, Brazil. Agricultural Systems, v. 137, p. 206-219, 2015. http://dx.doi.org/10.1016/j.agsy.2014.11.004.

CARNEIRO, L. A. M.; LINS, M. C.; GARCIA, F. R.; SILVA, A. P.; MAULLER, P. M.; ALVES, G. B.; ROSA, A. C.; ANDRADE, J. R.; FREITAS-ALMEIDA, A. C.; QUEIROZ, M. L. Phenotypic and genotypic characterisation of Escherichia coli strains serogrouped as enteropathogenic E. coli (EPEC) isolated from pasteurised milk. International Journal of Food Microbiology, v. 108, n. 1, p. 1521, 2006. http://dx.doi.org/10.1016/j.ijfoodmicro.2005.10.010. PMid:16490272.

CHAPELLE, F. H. The significance of microbial processes in hydrogeology and geochemistry. Hydrogeology Journal, v. 8, n. 1, p. 41-46, 2000. http://dx.doi.org/10.1007/PL00010973.

CRISPIM, S. M. A.; FERNANDES, F. A.; FERNANDES, A. H. B. M.; SOARES, M. T. S.; LISITA, F. O.; DOMINGOS BRANCO, O.; FRANCO, E. Aplicação de dejetos suínos na producão de Tifton 85 em assentamento rural, São Gabriel do Oeste, MS. Corumbá: Embrapa Pantanal, 2010. 
FAO - FOOD AND AGRICULTURE ORGANIZATION OF THE UNITED NATIONS. FAOSTAT. Statistical Division of the Food and Agriculture Organization of the United Nations (FAO). Rome, 2015. Available from: <http://www.fao.org/faostat/ en/>. Access on: 18 feb. 2015.

FERNANDES, A. H. B. M.; CARDOSO, M. A.; SOUZA, R. A. C.; FERNANDES, F. A.; SOARES, M. T. S.; CRISPIM, S. M. A.; GALVANI, F.; LISITA, F. O. Nitrificação e mineralização de carbono em solos tratados com dejetos de suinos biodigeridos. Corumbá: Embrapa Pantanal, 2011.

FERRARO, A. A.; GABAS, S. G.; LASTORIA, G. Origem de metais pesados em Aquífero livre de São Gabriel do Oeste, Mato Grosso do Sul. Geociências (São Paulo), v. 34, n. 4, p. 801-815, 2015.

FRIDRICH, B.; KRČMAR, D.; DALMACIJA, B.; MOLNAR, J.; PEŠIĆ, V.; KRAGULJ, M.; VARGA, N. Impact of wastewater from pig farm lagoons on the quality of local groundwater. Agricultural Water Management, v. 135, p. 40-53, 2014. http:// dx.doi.org/10.1016/j.agwat.2013.12.014.

GILLER, K. E.; BEARE, M. H.; LAVELLEC, P.; IZAC, A.M.N.; SWIFT, M. J. Agricultural intensification, soil biodiversity and agroecosystem function. Applied Soil Ecology, v. 6, n. 1, p. 3-16, 1997. https://doi.org/10.1016/S0929-1393(96)00149-7.

GONZALEZ, A. M.; PARANHOS, R.; LUTTERBACH, M. S. Relationships between fecal indicators and pathogenic microorganisms in a tropical lagoon in Rio de Janeiro, Brazil. Environmental Monitoring and Assessment, v. 164, n. 1-4, p. 207219, 2010. http://dx.doi.org/10.1007/s10661-009-0886-9. PMid:19365609.

GUEDES, J. C. S.; SALLES, A. T. Estruturação de um sistema de informações geográficas no projeto de assentamento Campanário: município de São Gabriel do Oeste, MS. In: SIMPÓSIO DE GEOTECNOLOGIAS NO PANTANAL, 1., 2006, Campo Grande, Anais.... São José dos Campos: INPE, 2006.

HERMANS, S. M.; BUCKLEY, H. L.; CASE, B. S.; CURRANCOURNANE, F.; TAYLOR, M.; LEAR, G. Bacteria as emerging indicators of soil condition. Applied and Environmental Microbiology, v. 83, n. 1, p. e02826-e16, 2017. PMid:27793827.

HONG, P.-Y.; YANNARELL, A.; DAI, O.; EKIZOGLU, M.; MACKIE, R. Monitoring the perturbation of soil and groundwater microbial communities due to pig production activities. Applied and Environmental Microbiology, v. 79, n. 8, p. 2620-2629, 2013. http://dx.doi.org/10.1128/AEM.03760-12. PMid:23396341.

HUMPHREYS, W. F. Hydrogeology and groundwater ecology: Does each inform the other? Hydrogeology Journal, v. 17, n. 1, p. 5-21, 2009. http://dx.doi.org/10.1007/s10040-008-0349-3.
HUNT, R. J.; JOHNSON, W. P. Pathogen transport in groundwater systems: contrasts with traditional solute transport. Hydrogeology Journal, v. 25, n. 4, p. 921-930, 2017. http://dx.doi.org/10.1007/ s10040-016-1502-z.

KIM, H.; KIM, K. Microbial and chemical contamination of groundwater around livestock mortality burial sites in Korea - a review. Geosciences Journal, v. 16, n. 4, p. 479-489, 2012. http:// dx.doi.org/10.1007/s12303-012-0036-1.

KLOVE, B.; KVITSAND, H. M. L.; PITKANEN, T.; GUNNARSDOTTIR, M. J.; GAUT, S.; GARDARSSON, S. M.; ROSSI, P. M.; MIETTINEN, I. Overview of groundwater sources and water-supply systems, and associated microbial pollution, in Finland, Norway and Iceland. Hydrogeology Journal, v. 25, n. 4, p. 1033-1044, 2017. http://dx.doi.org/10.1007/ s10040-017-1552-x.

LIU, H.; LEI, T. W.; ZHAO, J.; YUAN, C. P.; FAN, Y. T.; QU, L. Q. Effects of rainfall intensity and antecedent soil water content on soil infiltrability under rainfall conditions using the run offon-out method. Journal of Hydrology (Amsterdam), v. 396, n. 1, p. 24-32, 2011. http://dx.doi.org/10.1016/j.jhydrol.2010.10.028.

MANOEL FILHO, J. Contaminação de águas subterrâneas. In: FEITOSA, F. A. C. (Ed.). Hidrogeologia: conceitos e aplicações. 3. ed. Rio de Janeiro: CPRM/LABHID, 2008. p. 381-404.

MATO GROSSO DO SUL. Governo do Estado. Secretária de Estado do Meio Ambiente, do Planejamento, da Ciência e Tecnologia. Caderno Geoambiental das regiões de planejamento do MS. Campo Grande: SEMAC, 2011.

MCKAY, L. D. Foreword: pathogens and fecal indicators in Groundwater. Ground Water, v. 49, n. 1, p. 1-3, 2011. http:// dx.doi.org/10.1111/j.1745-6584.2010.00763.x. PMid:21039447.

MIELE, M.; MIRANDA, C. R. O desenvolvimento da agroindústria brasileira de carnes e as opções estratégicas dos pequenos produtores de suínos do Oeste Catarinense no início do século 21. In: CAMPOS, S. K.; SANTANA, C. (Org.). A pequena produção rural e as tendências do desenvolvimento agrário brasileiro: ganhar tempo é possível? Brasilia: CGEE - CENTRO DE GESTÃO E ESTUDOS ESTRATÉGICOS, 2013. p. 201-231.

MURPHY, H. M.; PRIOLEAU, M. D.; BORCHARDT, M. A.; HYNDS, P. D. Review: epidemiological evidence of groundwater contribution to global enteric disease, 1948-2015. Hydrogeology Journal, v. 25, n. 4, p. 981-1001, 2017. http://dx.doi.org/10.1007/ s10040-017-1543-y.

PAYMENT, P.; LOCAS, A. Pathogens in water: value and limits of correlation with microbial indicators. Ground Water, v. 49, n. 1, p. 4-11, 2011. http://dx.doi.org/10.1111/j.17456584.2010.00710.x. PMid:20477877. 
PENG, T.-R.; LU, W.-C.; CHEN, K.-Y.; ZHAN, W.-J.; LIU, T.-K. Groundwater-recharge connectivity between a hills-and-plains' area of western Taiwan using water isotopes and electrical conductivity. Journal of Hydrology (Amsterdam), v. 517, p. 226-235, 2014. http:/ / dx.doi.org/10.1016/j.jhydrol.2014.05.010.

SAAE - SERVIÇO AUTÔNOMO DE ÁGUA E ESGOTO. Relatório anual. São Gabriel do Oeste: Prefeitura de São Gabriel do Oeste, 2013.

SILVA, N.; JUNQUEIRA, V. C. A.; SILVEIRA, N. F. A.; TANIWAKI, M. H.; SANTOS, R. F. S.; GOMES, R. A. R.; OKAZAKI, M. M. Manual de métodos de análise microbiológica de alimentos e água. 4. ed. São Paulo: Editora Varela, 2010.

SOBESTIANSKY, J.; BARCELLOS, D. E. S. N. Doenças dos suínos. 2. ed. Goiânia: Cânone Editorial, 2007.

SOUZA, A. A.; LASTORIA, G.; GABAS, S. G.; MACHADO, C. D. Avaliação da água subterrânea nos aquíferos cenozóico e guarani em São Gabriel do Oeste-MS: subsídios à gestão integrada. Ciência e Natura, v. 36, n. 2, p. 169-179, 2014. http://dx.doi. org/10.5902/2179460X13174.

TAYLOR, R. G.; TODD, M. C.; KONGOLA, L.; MAURICE, L.; NAHOZYA, E.; SANGA, H.; MACDONALD, A. M. Evidence of the dependence of groundwater resources on extreme rainfall in East Africa. Nature Climate Change, v. 3, n. 4, p. 374-378, 2013. http://dx.doi.org/10.1038/nclimate1731.

TORTORA, G. J. Microbiologia. 10. ed. Porto Alegre: Artmed, 2012.

TRABULSI, L. R. T.; ALTERTHUM, F. Microbiologia. 6. ed. São Paulo: Atheneu, 2015.

WANG, A.; LIN, B.; SLEEP, B. E.; LISS, S. N. The impact of biofilm growth on transport of Escherichia coli O157:H7 in sand. Ground Water, v. 49, n. 1, p. 20-31, 2011. http://dx.doi. org/10.1111/j.1745-6584.2010.00690.x. PMid:20236334.

\section{Authors contributions}

Camila Bolognes Couto Pahl: Field sampling, writing, images elaboration, discussion and review.

Giancarlo Lastoria: Writing, discussion and review.

Sandra Garcia Gabas: Writing, discussion and review. 